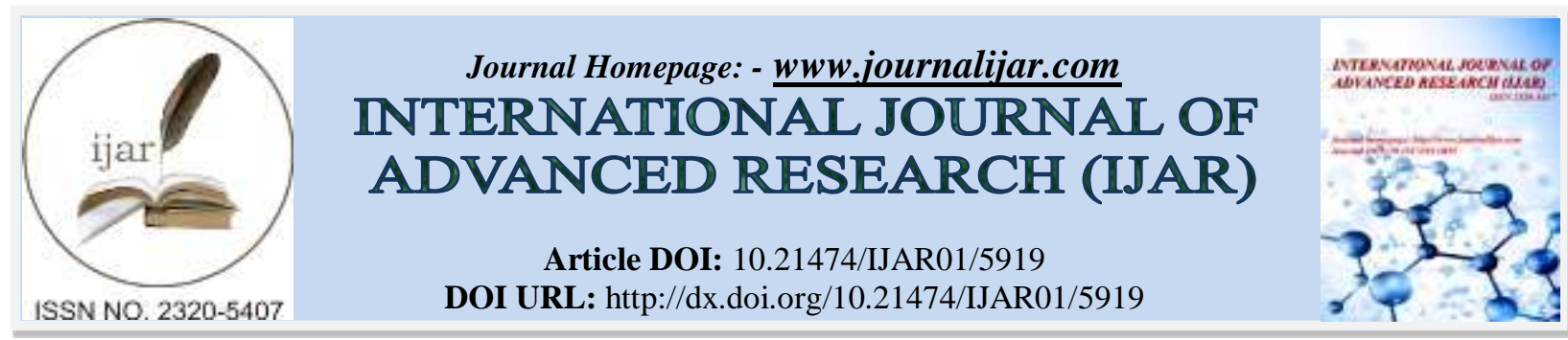

RESEARCH ARTICLE

\title{
IMPACT OF RISK MANAGEMENT ON THE PERFORMANCE OF COMMERCIAL BANKS , IN SRI LANKA.
}

\section{W. Percy Wijewardana ${ }^{1}$ and P. D. Wimalasiri ${ }^{2}$.}

1. Department of Accountancy and Finance, Faculty of Management Studies, Rajarata University of Sri Lanka, Mihintale, Sri Lanka.

2. Department of Business Management, Faculty of Management Studies, Rajarata University of Sri Lanka, Mihintale , Sri Lanka.

\section{Manuscript Info}

Manuscript History

Received: 19 September 2017

Final Accepted: 21 October 2017

Published: November 2017

Key words:-

Risk Management, Commercial Banks, Credit Risk.

\section{Abstract}

Risk management is a cornerstone of practical banking practice and mismatch of return is raised in economic issues in any country. Therefore the study examined how risk affects to the performance of commercial banks in Sri Lanka. For this purpose the current study selects credit risk, liquidity risk, operational risk and capital management risk as independent variables while return on assets and return on equity are utilized as dependent variables. The focus sample is covered by thirteen commercial banks for the period of six years from 2011 to 2016 and data analysed through SPSS package. The results of the study revealed that, operating risk has significant relationship with financial performance and capital management risk has significant relationship with only return on equity of commercial banks in Sri Lanka. Based on the research findings study recommended commercial banks have to control their operating risk, through operating expense level.

Copy Right, IJAR, 2017,. All rights reserved.

\section{Introduction:-}

All banks in the present-day context survive in the unstable environment and facing a large number of risks such as credit risk, liquidity risk, foreign exchange risk, market risk and interest rate risk etc. Those risks may threaten for all banks to survive and success in the market therefore efficient risk management is absolutely required for all banks. According to Richard and Safra (1996) there should maintain a balance between risk and return. When to consider about the banking sector they have to face those problems higher than other sectors. Trust is the important factor when to consider about the banking sector. Therefore banks must protect their trust by using the appropriate risk management practices. The main aim of financial institutions is to maximize revenues and offer the most value to shareholders by offering a variety of financial services, and especially by administering risks. In past decade Sri Lankan banking sector has growth continuously. For this situation mainly cause to economic development in Sri Lanka after the civil war. And also competition has been very high due to all of the banks try to maximize the wealth individually and new banks comes to the banking industry on day by day. Currently, Sri Lanka has 25 licensed commercial banks. The banking sector accounted for $83 \%$ of financial system assets at end 2016 and comprises licensed commercial banks $\left(\mathrm{LCB}_{\mathrm{s}}\right)$ and licensed specialized banks $\left(\mathrm{LSB}_{\mathrm{s}}\right)$. Due to the high competition most of organizations many commercial banks have appointed senior staff members to oversee a formal risk management function. According to Richard and Safra (1996) there should maintain a balance between risk and return. When to 
consider about the banking sector they have to face those problems higher than other sectors. Trust is the important factor when to consider about the banking sector. Therefore banks must protect their trust by using the appropriate risk management practices. Risk can be classified into systematic and unsystematic risk. Systematic risk is associated with the overall market or the economy, whereas unsystematic risk is related to a specific asset or firm. Some of the systematic risk can be reduced through the use of risk mitigation and transmission techniques. The objective of this study is to examine the impact of risk management on the Performance of Commercial Banks in Sri Lanka.

\section{Literature Review:-}

There have been a large number of studies published about risk management in general. However, the number of the empirical studies on risk management practices in financial institutions was found to be relatively small. The study theoretical review and empirical review as follows.

Stakeholder theory is most relevant to this study. Because a major objective of bank management is to increase shareholders' return signifying performance. Stakeholder theory helps to identify different risks and how to increase shareholder's return. Therefore stakeholder theory helps to identify the relationship between risk management and financial performance of banks. Freeman (1984) introduced the concept as a managerial instrument, has since evolved into a theory of the firm with high explanatory potential. Stakeholder theory focuses explicitly on equilibrium of stakeholder interest as the main determinant of corporate policy. According to Miller and Modigliani (1958), the theory of financial economic theory states that corporate risk management is appropriate to increase firm value in the presence of capital market imperfections such as bankruptcy costs, a convex tax schedule, or underinvestment problems. According to Williamson (1998), New Institutional Economics theory predicts that risk management practices may be determined by institutions or accepted practice within a market or industry. Further, the theory links security with specific assets purchase, which implies that risk management can be important in contracts which bind two sides without allowing diversification, such as large financing contract or close cooperation within a supply chain.

According to Yousfi (2012) study aims to determine the impact of risk management practices on Jordanian Islamic bank's performance. For this purpose, the current study selects credit risk, operational risk, liquidity risk and market risks as explanatory variables while return on assets (ROA) and return on equity (ROE) are utilized as dependent variables for the period of fifteen years from 1998 to 2012. Liquidity, credit and operational risk management practices have a negative and significant statistical impact on Islamic bank's performance, and these banks failed at the same time in managing these risks. Market risk management practices have a positive and significant statistical impact on bank's performance which, means that these banks don't suffer either from the operational risk during the study period or from managing this type of risk.

According to Santomero (1997), Liquidity risk can best be described as the risk of a funding crisis. While some would include the need to plan for growth and unexpected expansion of credit, the risk here is seen more correctly as the potential for a funding crisis. Such a situation would inevitably be associated with an unexpected event, such as a large charge off, loss of confidence, or a crisis of national proportion such as a currency crisis.

Kithinji (2010) examined the relationship between the credit risk management and profitability of commercial banks in Kenya. The findings reveal that the level of credit was high in the early years of the implemented of Basel II but decreased significantly in 2007 and 2008, probably when the Basel II was implemented by commercial banks. Notably, the level of nonperforming loans given by nonperforming loans to total loans decreased during the period 2004 to 2008. Thus on average the profits of the banking industry increased during the period 2004 to 2008 . However, profitability of the commercial banks fluctuated during the period but on average increased marginally during the period 2004 to 2008. Kargi (2011) conducted a study on credit risk and the performance of Nigerian banks. Kargi used non-performing loan portfolios and these significantly contributed to financial distress in the banking sector. Financial ratios as measures of bank performance and credit risk were the data collected from secondary sources mainly the annual reports and accounts of sampled banks from 2004-2008. The author concluded that credit risk management has a significant impact on the profitability of Nigeria banks

Fan and Yijun (2014) investigated if there is a relationship between credit risk management and profitability of commercial banks in Europe. The research collects data from the largest 47 commercial banks in Europe from 2007 
to 2012. The findings reveal that credit risk management does have positive effects on profitability of commercial banks.

Sulieman (2014) conducted a study aims at examining the effect of credit risk management on the financial performance of the Jordanian commercial banks during the period (2005-2013), thirteen commercial banks have been chosen to express on the whole Jordanian commercial banks. Two mathematical models have been designed to measure this relationship, the research revealed that the credit risk management effects on financial performance of Jordanian commercial banks as measured by ROA and ROE. The research further concludes that the credit risk management indicators considered in this research have a significant effect on the financial performance of the Jordanian Commercial banks. According to the above empirical analysis studies reflected different kind of relationship between risk and commercial bank performance based on their result findings.

\section{Methodology:-}

In this section we describe our data and analytical aspect on the impact of risk management on the performance of risk management and basically this research data type is qualitative. Although we are not able to identify and analysis of all the type of risk which are likely used by the commercial bank, we believe that our approach provides a moving the current paradigm forward. By incorporating risk and performance into our analysis, we are able to evaluate the comparative advantages of commercial bank operation towards the effective and efficient. The study developed a conceptual framework presented on table 01 based on extensive literature survey and it presented at figure 1. According to the framework it is expected to use financial ratio on non-performing loan, liquidity, cost to income, capital ratio and return on asset and return on equity ratios. The dependent variable in this study is financial performance. It measure to return on assets (ROA) and return on equity (ROE). Independent variable in this study is risk management and the four aspects of risk management process. There are Credit risk, Liquidity risk, Operational risk and Capital management risk.

Figure 1:- Conceptual Framework

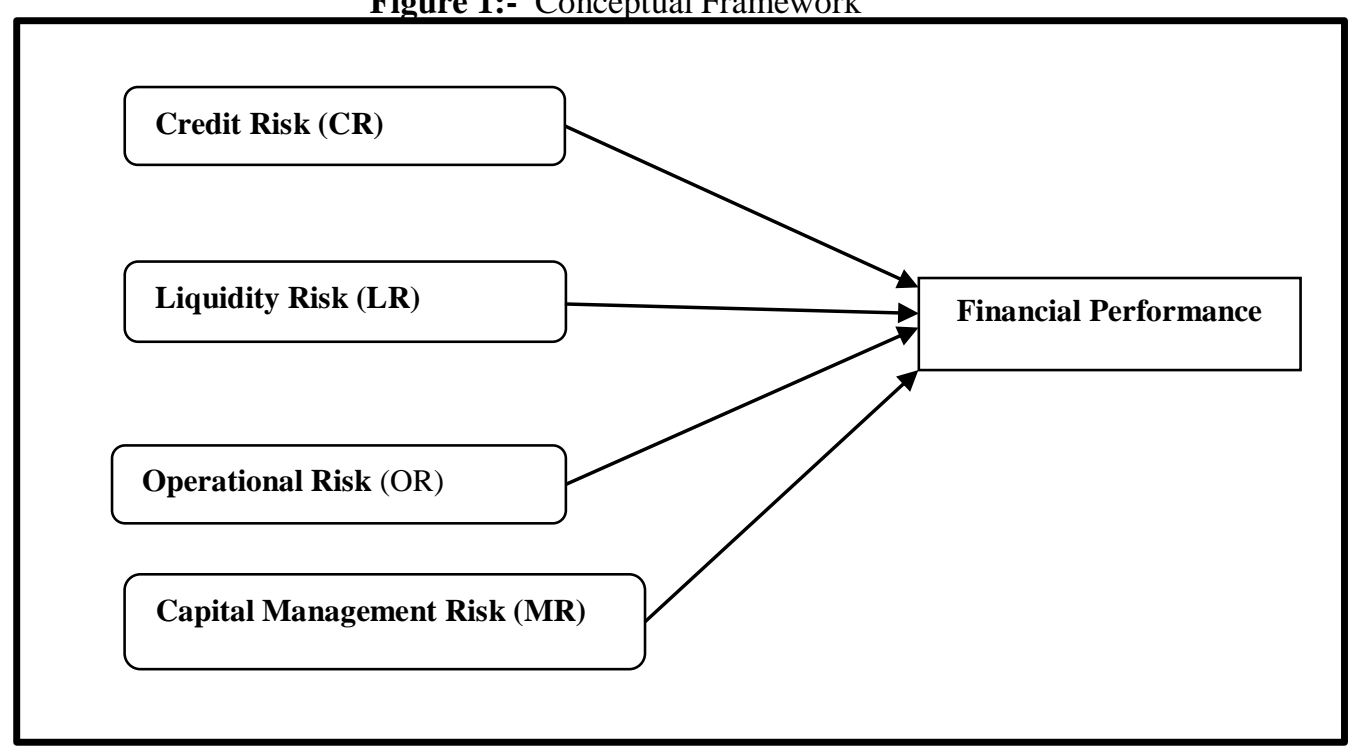

When considering previous researchers, Adeusi (2013) identify in his study dependent variable which represents bank profitability measured by the return on equity and return on asset. Independent variables which are represent liquidity, credit, and capital risks. Muteti (2014) state to dependent variable in his study is financial performance and independent variables are the credit risk, interest rate risk, foreign exchange risk, liquidity risk, bank size, bank deposits.

This study will test the following hypotheses to identify the relationship among variables.

If credit risk is not completely impact the performance, however, credit risk may impact higher performance for higher risk. In this case, higher bank credit risk increases and the bank performance moderate by other risk, leading bank shareholders to adhere to a lower credit risk ratio in order to reduce the cost of funding and predict the credit 
risk will have a positive influence on Return on equity. Credit risk issues may, in the case of convey positive information to the Return on the bank equity holders.

Moreover, increasing credit risk via increases in credit may require a bank to expect positive net return. Commercial Banks may thus prefer to hold a "buffer" of excess credit availability to make it higher likely they will higher below the legal credit requirements. This reason would be enough to encourage banks to establish liquidity buffers even if funds were totally invest the banking operations, and there were no cost of financial distress associated with the loss of charter value. Brown and Davis (2009) show the relevance of adjustments when a limited access to external equity capital in mutual financial institutions leads them to have higher capital ratios. It directly affects the credit risk. On the basis of above our first hypothesis is:

$\mathrm{H}_{1}$ : Commercial Bank credit risk is negatively related to return on equity and return on assets if bank credit risk changed its affect to change negatively on Return on equity and assets.

We postulate that the expected positive influence of capital management risk and return on equity and assets, depending on bank regulation, bank supervision, and a country's institutions. We analyze the impact of the quality of capital management, the generosity of return on assets and equity, restrictions on management activities, official supervisory power, and the quality of a banking system and institutions. Therefore, if the quality of capital management favors greater risk related discipline, we expect the capital management risk to have a greater positive influence on bank return on assets and equity. We therefore expect to note higher capital management risk in commercial bank return. Accounting capital management requirements may also have an effect on bank return; the quality of bank services is negatively related to capital management risk. Reductions in spreads may increase bank return and thus mitigate bank risk-taking capital management related risk. In this context, the second hypothesis is:

$\mathrm{H}_{2}$. Severer capital management requirement standards encourage reduce capital management risk to increase both the return on equity and return on assets with the increase of overall banking performance.

It has long been suggested that more substantial liquidity weakens the market discipline enforced by depositors and encourages banks to take greater risks of liquidity and ultimate influence to the return on assets and equity. It is showing that deposit insurance increases the likelihood of banking liquidity crises and that liquidity risk-shifting incentives are positively related to the overall banking performance. If more generous deposit reduces liquidity risk, it will also make the cost of deposits less sensitive to bank risk and reduce the optimum liquidity capital ratio for commercial banks. For this reason, we forecast that the positive relation between the cost of deposits and the liquidity risk will be weaker depending on the bounty of the deposit strengthening. There is little attention on the influence of the generosity of deposit strengthening on bank risk. To our knowledge, offers evidence on this issue, finding a positive relation between the presence of explicit liquidity risk and the return. A positive relation would provide banks that have explicit deposit increase with incentives to maintain liquidity capital adequacy to preserve their higher liquidity risk value both return on assets and return on equity. If liquidity diminishes liquidity risk diminishes market discipline but increases bank return on equity, its predominant effect on liquidity capital management becomes an empirical question. The third hypothesis is:

$\mathrm{H}_{3}$ : More generous deposits make liquidity capital defenses less important in increasing liquidity risk but more important in reducing the cost of liquidity related distress positively related to increase the return on assets and equity.

One further regulatory variable is whether commercial banks are allowed to undertake operational activities that generate non-interest income this study identify as operational risk.

Formulated the restrictions on bank operational activities may affect returns, as constraints on a commercial bank's range of operational activities limit the opportunities for commercial bank managers to operate risky investments. Relaxation of market discipline will make it less beneficial for a commercial bank to hold capital adequacy. It shows that when long-standing operational risk on permissible bank activities was controlled, banks raised their income as a consequence of enhanced market discipline. We thus expect higher the operational risk limited on bank income to make the return of assets and equity less sensitive to bank operational risk. Based on those restrictions on bank operation activities have a negative influence on return. We would accordingly expect that the stricter the 
restrictions on bank activities, the greater the positive influence of operational risk on commercial bank return on both assets and equity.

The theoretical embarking effect that restriction on bank operational risk activities may have on returns both equity and assets are considered in our fourth hypothesis, making their analysis an empirical question.

$\mathrm{H}_{4}$ : Higher restrictions on bank operational activities make operational risk higher important in reducing the return on equity and assets but more important in reducing the operational risk of bank activities.

Study primary data from the 2011 to 2016 collected from annual statements of listed commercial banks traded in Colombo Stock exchange, and entire population in this sector contained 25 commercial banks. Study sample comprised on thirteen commercial banks has selected as a study sample and based on the random sample technique. Although in this sector more firm have other financial, insurance and finance companies. First section discuss the descriptive statistics of the study to understand the primal behavior of the data using mean, maximum, minimum and standard deviation parameters of the study variables. Second section is devoted to analysis the correlation metrics to identify the relationship among the study variables. We employed the generalized method of multiple regression estimator developed for dynamic models of study data. This methodology is specifically designed to address three relevant econometric issues: (1) the presence of unobserved bank-specific effects; (2) the autoregressive process in the data regarding the behavior of commercial bank behavior; and (3) the likely endogeneity of the explanatory variables. Study empirical methodological analytical model is designed to test the empirical prediction of the current paradigm whether risk categorical impact on the equity and operational performance of the banks, how those risk measures are influence the equity and operational performance. Our first model specification have designed to analysis the risk associate with the four overall risk aspects of the bank influence on bank performance as identified as equity measurement. The second model specification has designed to analysis same risk variables on bank performance identify as asset measurement.

\section{General Model:-}

Bank Performance $=\alpha+\beta_{1}$ CreditRisk $+\beta_{2}$ Liquidity Risk $+\beta_{3}$ Operating Risk $+\beta_{4}$ CapitalManageing Risk $+\delta . .$. Eq 1

Where; $\mathrm{Y}$ is the commercial bank financial performance is labels returns on assets (ROA) and equity (ROE) as the dependent variables for two models. We measures the credit risk (CR), liquidity risk (LR), operating risk (OR) and capital management risk (MR) as the independent variables.

Study Model 1:-

$R O A=\alpha+\beta_{1} C R_{1}+\beta_{2} L R_{2}+\beta_{3} O R_{3}+\beta_{4} M R_{4}+\delta \ldots . . E q 2$

Study Model 2:-

$R O A=\alpha+\beta_{1} C R_{1}+\beta_{2} L R_{2}+\beta_{3} O R_{3}+\beta_{4} M R_{4}+\delta \ldots . . E q 3$

\section{Result and Discussion:- \\ Descriptive Analysis:-}

Descriptive analysis provides simple summaries about the sample and the observations that have been made to describe the data distribution of the study.

Graph 1:-

Descriptive Statistic 


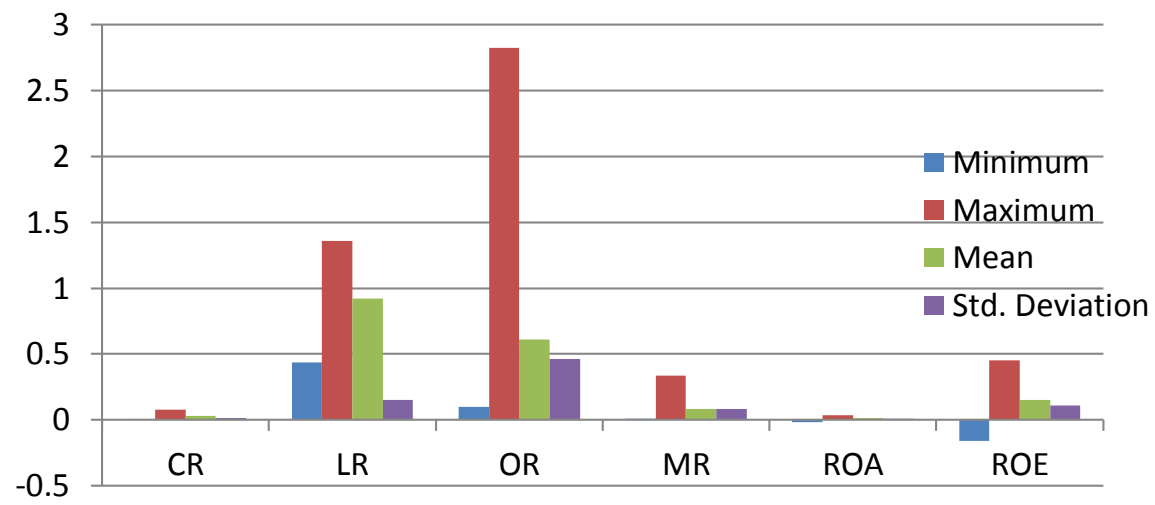

According to the descriptive statistical analysis graph 1 highest maximum value (2.823) shows the operating risk and lowest minimum value shows (0.004) by the credit risk. All risk were between $0.004-2.823$. The mean value of credit risk indicates that when the increase of total loan in hundred, nonperforming loan is increased $2.9 \%$. The mean value of capital management indicates that when increase of total assets hundred, capital and reserves are increased $8.1 \%$. The mean value of liquidity risk indicates that when the increase in total deposits hundred, the total loan is increased $92.1 \%$. When considering mean value of operational risk gross earnings increased hundred, operational expense increased in $60.8 \%$.

\section{Correlation Analysis:-}

A correlation coefficient is a statistical measure of the degree to which changes to the value of one variable predict change to the value of another. And also it represents the relationship between two variables.

Table 2:- Descriptive statistics and Correlations Analysis

\begin{tabular}{|l|c|c|c|c|c|c|}
\hline & CR & LR & OR & CMR & ROA & ROE \\
\hline Minimum & 0.004 & 0.438 & 0.099 & 0.007 & -0.019 & -0.160 \\
Maximum & 0.078 & 1.358 & 2.823 & 0.335 & 0.038 & 0.452 \\
Mean & 0.029 & 0.921 & 0.608 & 0.080 & 0.012 & 0.150 \\
\hline Standard Deviation & 0.015 & 0.150 & 0.464 & 0.082 & 0.008 & 0.108 \\
\hline Credit Risk (CR) & 1 & & & & & \\
\hline Liquidity Risk (LR) & -0.225 & 1 & & & & \\
& $(0.72)$ & & & & & \\
\hline Operating Risk(OR) & -0.050 & $-0.417^{* *}$ & 1 & & & \\
& $(0.695)$ & $(0.001)$ & & & & \\
\hline Capital Management Risk(CMRC) & -0.106 & -0.009 & $0.483^{* *}$ & 1 & & \\
& $(0.401)$ & $(0.940)$ & $(0.000)$ & & & \\
\hline ROA & -0.057 & $0.395^{* *}$ & $0.644^{* *}$ & $0.430^{* *}$ & 1 & \\
& $(0.654)$ & $(0.001)$ & $(0.000)$ & $(0.000)$ & & \\
\hline ROE & -0.051 & 0.081 & $-0.590^{* *}$ & $-0.661^{* *}$ & $0.679^{* *}$ & \\
& $(0.688)$ & $(0.521)$ & $(0.000)$ & $(0.000)$ & $(0.000)$ & \\
\hline
\end{tabular}

Source: Study analysis $2017, * *$. Correlation is significant at the 0.01 level (2-tailed).

According to the correlation analysis, credit risk, capital management risk and operational risk have the negative relationship with ROA and credit risk has significant relationship with ROA. Operational risk and capital management risk have the higher negative correlation with ROA. It indicates that operational risk and capital management risk highly affect the decrease ROA. Credit risk, operational risk and capital management risk have the negative relationship with ROE. Considering liquidity risk has low positive and significant relationship with ROE. Capital management risk and operating risk highly affect the decrease ROE. Considering both of ROA and ROE, operating risk and capital management risk negatively affect decrease the bank's performance. 


\section{Multiple Regression Results:-}

We present the results of estimating the multiple regressions for bank financial performance sample in table 3 and 4. The model 1 table 3 appears to fit the data well $(\mathrm{F}$ - value $=0.00)$, and ROA is significantly and negatively related operating risk. Since the other risk factors such as credit, liquidity, and capital management risk negatively related but not significant. The problem of heteroscedasticity also does not exist in the data set as Durbin Watson value (1.758) gets closer to the critical value 2 . The expletory power $\left(\mathrm{R}^{2}\right)$ of the model was 46.8 . Accordingly, variation of $46.8 \%$ on the financial performance in term of ROA of commercial bank due to changes in credit risk, liquidity risk, operational risk and capital management risk.

Table 3:- Coefficients of Model ROA

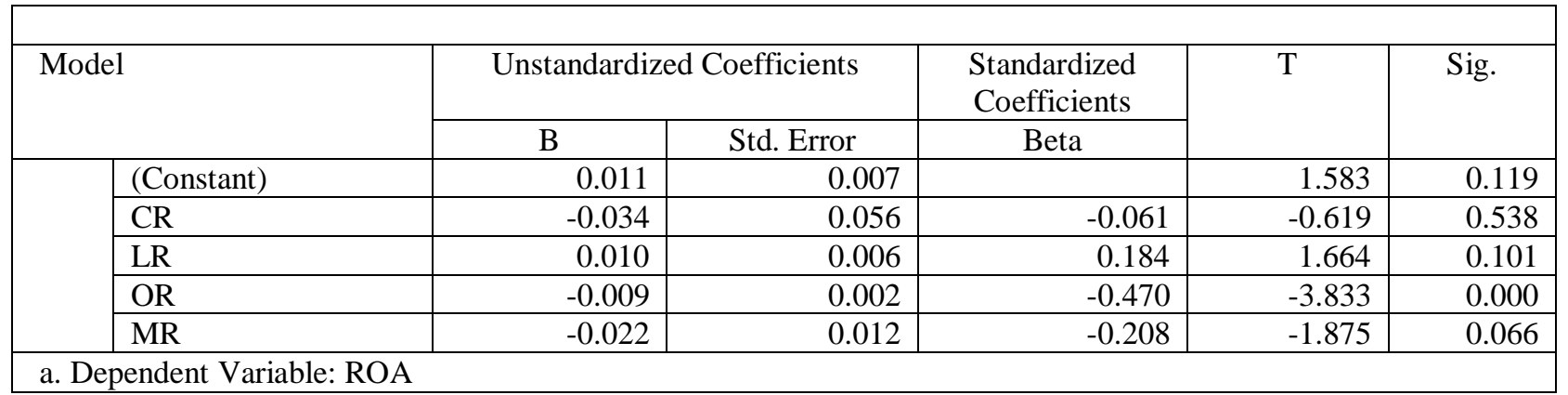

Model Summary Statistics:-

\begin{tabular}{|c|c|c|c|c|}
\hline Model & $\mathrm{R}$ & R Square & Adjusted R Square & Std. Error of the Estimate \\
\hline ROA & $0.6840^{\mathrm{a}}$ & 0.4680 & 0.4330 & 0.0064 \\
\hline
\end{tabular}

$$
R O A=0.011-0.034 C R+0.010 L R-0.0090 R-0.022 C M P
$$

The above regression equation it was revealed that holding credit risk, liquidity risk, operational risk, capital management risk, return on assets of commercial banks would be at 0.011 , a unit increase in credit risk would lead to decrease in return on assets of commercial banks by factors 0.034 , a unit increase in liquidity risk would lead to increase in return on assets by factors of 0.010 , a unit increase operational risk would lead to decrease in return on assets of commercial banks by a factors 0.009 , a unit increase in capital management risk would lead to decrease in return on assets of commercial banks by a factors 0.022 . In table 4 , we present the results from a second regression for return on equity sample. The model appears to fit the data well ( $p$ value-0.00), and, as expected the dependent variable in terms of return on assets is significantly and positively related to operating and capital management ratios. We also do not found that credit and liquidity ratios significantly associate with return on equity, but insignificantly and negatively associated with return on equity. The expletory power $\left(\mathrm{R}^{2}\right)$ of the model was $54.1 \%$. Accordingly, variation of $54.1 \%$ on the financial performance in term of ROE of commercial bank due to changes in credit risk, liquidity risk, operational risk and capital management risk.

Table 4:- Coefficients and model summary of Model ROE

\begin{tabular}{|c|c|c|c|c|c|}
\hline \multirow[t]{2}{*}{ Model } & \multicolumn{2}{|c|}{ Unstandardized Coefficients } & \multirow{2}{*}{$\begin{array}{l}\text { Standardized Coefficients } \\
\text { Beta }\end{array}$} & \multirow[t]{2}{*}{$\mathrm{T}$} & \multirow[t]{2}{*}{ Sig. } \\
\hline & $\mathrm{B}$ & Std. Error & & & \\
\hline (Constant) & 0.336 & 0.082 & & 4.085 & 0.000 \\
\hline $\mathrm{CR}$ & -0.305 & 0.653 & -0.042 & $\begin{array}{r}- \\
0.466\end{array}$ & 0.643 \\
\hline LR & -0.075 & 0.074 & -0.103 & 1.009 & 0.317 \\
\hline OR & -0.095 & 0.027 & -0.409 & $\begin{array}{r}- \\
3.588\end{array}$ & 0.001 \\
\hline MR & -0.616 & 0.135 & -0.469 & $\begin{array}{r}- \\
4.554\end{array}$ & 0.000 \\
\hline
\end{tabular}




\begin{tabular}{|l|l|l|l|l|}
\hline Model & $\mathrm{R}$ & $\begin{array}{l}\mathrm{R} \\
\text { Square }\end{array}$ & $\begin{array}{l}\text { Adjusted } \\
\text { R Square }\end{array}$ & $\begin{array}{l}\text { Std. Error of } \\
\text { the Estimate }\end{array}$ \\
\hline ROE & $0.735^{\text {a }}$ & 0.541 & 0.510 & 0.0456 \\
\hline \multicolumn{2}{|l}{ a. Predictors: (Constant), Capital management risk, Liquidity risk, Credit risk, Operational risk } \\
\hline
\end{tabular}

$R O E=0.336-0.305 C R-0.075 L R-0.095 R-0.616 C M R$

The above regression equation it was revealed that holding credit risk, liquidity risk, operational risk, capital management risk, return on assets of commercial banks would be at 0.336 , a unit increase in credit risk would lead to decrease in return on equity by factors of 0.305 , a unit increase in liquidity risk would lead to decrease in return on equity by factors of 0.075 , a unit increase operational risk would lead to decrease in return on equity of commercial banks by a factors 0.095 , a unit increase in capital management risk would lead to decrease in return on equity of commercial banks by a factors 0.616. According to above regression results, the effect of credit risk and liquidity risk were significant relationship with return on equity. Operational risk, capital management risks significant relationship with return on equity of commercial banks. Further, therefor we find that previously unrecognized capital management risk factor impact on bank performance significantly. Under the hypothesis testing analysis study hypothesis one is; Commercial Bank credit risk is negatively related to return on equity and return on assets if bank credit risk changed its affect to change negatively on return on equity and assets accepted. Second hypothesis is; severer capital management requirement standards encourage reduce capital management risk to increase both the return on equity and return on assets with the increase of overall banking performance is accepted. Third hypothesis is; more generous deposits makes liquidity capital defenses less important in increasing liquidity risk but more important in reducing the cost of liquidity related distress positively related to increase the return on assets and equity, hypothesis is accepted. This implication is more important when increase the liquidity basically bank can maintain the liquidity levels in low cost at the same time liquidity risk minimizes to help to increase the bank performance. Study hypothesis four is higher restrictions on bank operational activities may operational risk higher important in reducing the return on equity and assets but more important in reducing the operational risk of bank activities. Study is accepted the hypothesis. Continues management alert policy in the banking sector is compulsory when loose the managing alert simultaneously risk level of the capital management does not contribute to optimize the bank performance. Close monitoring and managing drivers are essential and compulsory part of the banking industry.

\section{Conclusion and Recommendation:-}

This study analyzes the impact risk Management on the Performance of Commercial Banks in using a data of 13 banks between 2011 and 2011. We employ the multiple regression estimators to control for credit risk, operating risk, liquidity and capital management risk of the explanatory variables. The results suggest that banks hold capital management risk, the lower the return on equity and the negative affect their return. The negative influence of the operating risk mirrors the return on assets in our sample. The negative influence of operating risk is consistent with evidence exploring that banks with higher risk value have fewer low return on assets and need higher supervision and control to reduce the non-performing loans. Moreover, our results highlight that bank regulation, supervision, and institutions alter the influence of the credit risk management as well as other risks and market power on credit management power across competitors. Restrictions on bank activities and official supervision increase the loan collecting power to increase repayment ability by weakening non-performing loan balance accumulating, but at the same time promote higher repayment mechanism by reducing the non-payment loan balance market power. The net effect is negative for risk variables. Commercial bank operational quality with regards to overall risk aspect has two opposite effects to restrictions on bank operational activities and bank managers and other official supervision. The net influence on capital buffers is negative. Inflexible information disclosure requirements and less substantial nonperformance loan recovery, however, have a clear positive effect on ROA by both strengthening market discipline and making competitive value better able to reduce overall risk-taking bank management. These results relate to the literature that finds a negative relation between operating risk and financial performance in term of return on equity because they suggest that better bank disclosure or less performing in non-performing loan may be ways to make greater banking competition compatible with greater financial stability and strength. Risk related aspect of the liquidity, credit and capital management on return on assets are negatively associated with return on assets. Our analysis has three basic implications for risk policies. First, one should not always assume that credit risk capital standards inevitably constrain a bank performance. Bank credit risk by themselves may induce banks to hold return above the minimum stipulated, thereby reducing the risk optimizing of bank return requirement as instruments of 
financial stability and profitability. Bank capital management requirement and supervisors should recognize that the effectiveness of regulatory capital requirements, depending on current bank regulation, official supervision, and the quality of accounting information and institutions. It is concluded that bank capital management requirements is essential management requirement to increase the performance of the banks. There is strongly understood conclusion validated in this study too, who control a country's banking matters. Controlling for capital market development and initial economic issues, we found that national banking systems entrusted more predominant to tycoons and business performance, hence banking performance subsequently seeks to enhance the country development.

\section{Reference:-}

1. Adeusi, S., Akeke, A., \& Adebisi, O. (2013). Risk managent and financial performance of Banks in Nigeria. Journal of Business and Management .

2. Brown, C., Davis, K., 2009. Capital management in mutual financial institutions. Journal of Banking and Finance 33, 443-455.

3. Fan, L., \& Yijun, Z. (2014). The impact of credit risk management on profitability of commercial banks. . A study of Europe, Umea School of Business and Economics .

4. Freeman, R. E. (1984). Strategic management. . A stakeholder approach,Prentice hall,Englewood Cliffs,NJ.

5. Kargi, , H. (2011). (pp. Credit risk and the performance of Nigerian banks. an unpublished MBA project,). Ahmadu Bello University,Zaria,Nigeria .

6. Kithinji, A. (2010). Credit risk and the performance of Nigerian banks. an unpublished MBA project, . School of business, University of Nairobi, Kenya.

7. Miller, M., \& Modigliani, F. (1958). A correction,American Economic Review ., (p. Corporate Income Taxes and the Cost of Capital.).

8. Muteti, , S. (2014). Relationship between financial risk management and financial performance of commercial banks in Kenya. An unpublished MBA project,School of Business,University of Nairobi,Kenya.

9. Richard, J., \& Safra, J. (1996). . : The Implications for Risk Management and Regulation, . The Collapse of Continental Illinois National Bank and Trust Company Professor of International Banking. The Wharton School, University of Pennsylvania.

10. Santomero. (1997). Commercial Bank Risk Management. An Analysis of the process, Journal of FinancialCommercial Bank Risk Management. An Analysis of the process, . Journal of Financial Services Research.

11. Sulieman, A. (2014). The effect of credit risk management on financial performance. Investment Management and Financial Innovations.

12. Williamson, O. (1998). The Institution of Governance. The AEA Papers and Proceedings . 